\title{
Osteometric Measurements of Intermastoid Distance for Gender Determination
}

\author{
Vamshi Ram V' and Yuvaraj Babu $\mathrm{K}^{2^{*}}$ \\ ${ }^{1}$ Saveetha Dental College and Hospitals, Saveetha Institute of Medical \\ and Technical Sciences, Saveetha University, Chennai -600077, India \\ ${ }^{2}$ Assistant professor, Department of Anatomy, Saveetha Dental College and Hospitals, \\ Saveetha Institute of Medical and Technical Sciences, Saveetha University, Chennai -600077, India
}

\begin{abstract}
The mastoid process is a bony pyramidal projection from the posterior section of the temporal bone. The superior border of the mastoid process of the temporal bone articulates with the parietal bone. The posterior border articulates with the occipital bone, and the anterior border is merged with the descending portion of the squamous segment of the temporal bone. The aim of the study is to determine the gender using the measurement of intermastoid distance. This study was conducted among 30 boys and 30 girls who were studying Ist year in Saveetha dental college of age 18 to 20. The measurement of intermastoid distance was taken using the spreading caliber. The measurements were tabulated systemically. Then by using an unpaired t- test calculator, the T- value and P- value of the study is calculated. The study concludes that the gender can be determined by using the measurements of intermastoid distance.
\end{abstract}

\section{KEY WORDS: MASTOID PROCESS, INTERMASTOID DISTANCE, SEX DETERMINATION, SPREADING CALIBER .}

\section{INTRODUCTION}

The mastoid process is a bony pyramidal projection from the posterior section of the temporal bone. The superior border of the mastoid process of the temporal bone articulates with the parietal bone. The posterior border articulates with the occipital bone, and the anterior border is merged with the descending portion of the squamous segment of the temporal bone (Galdames, Matamala and Smith, 2008; Sharma, Nidugala and Avadhani, 2013). Determination of sex in fragmented remains is often a difficult task, as no isolated characteristic of any specific

\section{ARTICLE INFORMATION}

${ }^{*}$ Corresponding Author: yuvarajbabu@saveetha.com

Received 25th June 2020 Accepted after revision 10th August 2020 Print ISSN: 0974-6455 Online ISSN: 2321-4007 CODEN: BBRCBA

Thomson Reuters ISI Web of Science Clarivate Analytics USA and Crossref Indexed Journal

\section{Clarivate
Analytics}

NAAS Journal Score 2020 (4.31) SJIF: 2020 (7.728)

A Society of Science and Nature Publication,

Bhopal India 2020. All rights reserved.

Online Contents Available at: http//www.bbrc.in/

Doi: http://dx.doi.org/10.21786/bbrc/13.7/93 bone can perfectly decide the sex of a skeleton. The maximum accuracy in sex determination is finished when the complete skeleton is available (Thejeswar and Thenmozhi, 2015; Kumar et al., 2016). But frequently fragmentary remains are available, as opposed to whole skeletons for forensic evaluation. Furthermore, a petrous part of temporal bone is proof against destruction and damage such as burning (Sumati et al., 2010; Geethika and Thenmozhi, 2016). The mastoid process is favorable for sex determination as it's one of the most protected vicinity and proof against harm because of its anatomical position at the bottom of the skull (Galdames, Matamala and Smith, 2008; Sharma, Nidugala and Avadhani, 2013; Passey et al., 2015; Dofe et al., 2020).

There are many researchers going on different anatomical features for gender determination. Jeyasingh et al, have estimated the orbital index for determination of gender (Jeyasingh and Devi, 2016). Hartomo et al, have compared the intercanine and intermolar width of the maxilla as an aid in gender determination (Hartomo et 
al., 2019). Kumar et al, have done determination of sex using human mandible (Kumar and Lokanadham, 2013). Previously our department has published extensive research on various aspects of dentistry (Begum et al, 2017; Ganapathy, Kannan and Venugopalan, 2017; Jain, 2017a, 2017b; Ranganathan, Ganapathy and Jain, 2017; Ariga et al., 2018; Gupta, Ariga and Deogade, 2018; Anbu et al., 2019; Ashok and Ganapathy, 2019; Duraisamy et al., 2019; Varghese, Ramesh and Veeraiyan, 2019), this vast research experience has inspired us to research about determining the gender using intermastoid distance. The main objective of the present study was to collect metric data of intermastoid distance among 30 boys and 30 girls and to check whether the intermastoid distance can be used in determination of sex.

\section{MATERIAL AND METHODS}

This study was conducted among 30 boys and 30 girls who were studying Ist year Dental in Saveetha Dental College of age group 18 to 20. The study was approved by SRB of Saveetha Dental College \& Hospitals and after getting informed consent the measurement of intermastoid distance was taken using the spreading caliber. The measurements of intermastoid distance which was obtained was noted for all 30 boys and 30 girls. Then the measurements were tabulated systematically. From the tabulated measurements, the lowest and highest value and the mean value was calculated. Then by using the unpaired t- test calculator the t- value and the $p$ - value was calculated. The mean and standard deviation was found for both boys and girls separately.

\section{RESULT AND DISCUSSION}

Males: The range of the intermastoid distance of boys are $11.5-12.7 \mathrm{~cm}$

The average is $12.11 \pm 0.12 \mathrm{cms}$

Females: The range of intermastoid distance of girls are $10.3-11.7 \mathrm{~cm}$

The average is $11.01 \pm 0.2 \mathrm{cms}$.

The t- value calculated 10.673

The $\mathrm{p}$ - value calculated was $0.00001(<0.05)$

The result is significant at $p<0.05$

The result shows when statistically comparing the data between males and females, the intermastoid distance was a reliable measurement for gender determination.

Identification is the basis of individuality of a person. Skeleton is the part of the body that resist all environmental insults for maximum time and can help to determine the sex. For identification one requires standard criteria which are specifically based to the group to which the person belongs. Each mastoid parameter is discussed by comparing them with the findings of previous workers. Mastoid process has been selected because it is well preserved and the most protected part of a fragmentary skull. The present study has provided a baseline data for sex determination of skull and also stressed the accuracy of intermastoid distance.

It has already shown that people in different regions, different races and ethnic groups vary considerably in proportion of their respective skeletal frame(Verma, 1996; Galdames, Matamala and Smith, 2008). The determination of the sex can be done by many parts of the skeletal frame. (Jeyasingh and Devi, 2016) has used an orbital index to determine gender. (Iscan, Yasar Iscan and Miller-Shaivitz, 1984) has used measurement of the tibial shaft to determine gender. (Vora et al., 2019) has determined sex using femur breadth. (Kumar and Lokanadham, 2013) has used human mandibles to determine gender. (Krüger, L’Abbé and Stull, 2017) estimated sex using the long bones of modern South Africans.

The limitation of the study is it can be done in a larger population so that we can also be taken for the people in the age group more than 25 but we have taken it among the college students.

\section{CONCLUSION}

The present study concluded that male samples with higher values than female samples. The intermastoid distance was a reliable measurement in determining the gender. So it is proved that the intermastoid distance can be used to determine the gender.

\section{ACKNOWLEDGEMENTS}

We acknowledge all the participants who have volunteered to take part in our research.

Conflict of Interest: The author declares that there is no conflict of interest in the present study.

\section{REFERENCES}

Anbu, R. T. et al. (2019) 'Comparison of the Efficacy of Three Different Bone Regeneration Materials: An Animal Study', European journal of dentistry, 13(1), pp. 22-28.

Ariga, P. et al. (2018) 'Determination of Correlation of Width of Maxillary Anterior Teeth using Extraoral and Intraoral Factors in Indian Population: A Systematic Review', World Journal of Dentistry, 9(1), pp. 68-75.

Ashok, V. and Ganapathy, D. (2019) 'A geometrical method to classify face forms', Journal of oral biology and craniofacial research, 9(3), pp. 232-235.

Dofe, M. Y. et al. (2020) 'Morphometric Study on Mastoid Process for Determination of Sex by Using 3D CT Scan', Indian Journal of Anatomy, pp. 85-89. doi: 10.21088/ ija.2320.0022.9120.13.

Duraisamy, R. et al. (2019) 'Compatibility of Nonoriginal Abutments With Implants: Evaluation of Microgap at the Implant-Abutment Interface, With Original and Nonoriginal Abutments', Implant dentistry, 28(3), pp. 289-295. 
Begum R, Ariga P, Ashish Jain 'Evaluation of Corrosive Behavior of Four Nickel-chromium Alloys in Artificial Saliva by Cyclic Polarization Test:An in vitro Study' (2017) World Journal of Dentistry, 8(6), pp. 477-482. Galdames, I. C. S., Matamala, D. A. Z. and Smith, R. L. (2008) 'Sex Determination Using Mastoid Process Measurements in Brazilian Skulls', International Journal of Morphology. doi: 10.4067/s071795022008000400025.

Ganapathy, D. M., Kannan, A. and Venugopalan, S. (2017) 'Effect of Coated Surfaces influencing Screw Loosening in Implants: A Systematic Review and Meta-analysis', World Journal of Dentistry, 8(6), pp. 496-502.

Geethika, B. and Thenmozhi (2016) 'Sex determination using the mastoid process using South Indian skulls', Research Journal of Pharmacy and Technology, p. 1869. doi: 10.5958/0974-360x.2016.00382.6.

Gupta, P., Ariga, P. and Deogade, S. C. (2018) 'Effect of Monopoly-coating Agent on the Surface Roughness of a Tissue Conditioner Subjected to Cleansing and Disinfection: A Contact Profilometric Study', Contemporary clinical dentistry, 9(Suppl 1), pp. S122S126.

Hartomo, B. T. et al. (2019) 'The use of human intercanine and intermolar for determining sex on natural disaster'. doi: 10.1063/1.5096753.

Iscan, M. Y., Yasar Iscan, M. and Miller-Shaivitz, P. (1984) 'Determination of sex from the Tibia', American Journal of Physical Anthropology, pp. 53-57. doi: 10.1002/ajpa.1330640104.

Jain, A. R. (2017a) 'Clinical and Functional Outcomes of Implant Prostheses in Fibula Free Flaps', World Journal of Dentistry, 8(3), pp. 171-176.

Jain, A. R. (2017b) 'Prevalence of Partial Edentulousness and Treatment needs in Rural Population of South India', World Journal of Dentistry, 8(3), pp. 213-217. Jeyasingh, T. and Devi, R. M. (2016) 'Determination of Sex by Using Orbital Index', Indian Journal of Forensic Medicine \& Toxicology, p. 56. doi: 10.5958/09739130.2016.00062.1.

Krüger, G. C., L'Abbé, E. N. and Stull, K. E. (2017)
'Sex estimation from the long bones of modern South Africans', International journal of legal medicine, 131(1), pp. 275-285.

Kumar, A. T. S. et al. (2016) 'Sex Determination Through Mastoid Process among South Indian Skulls by Heron's Formula', Indian Journal of Forensic Medicine \& Toxicology, p. 30. doi: 10.5958/09739130.2016.00008.6.

Kumar, M. and Lokanadham, S. (2013) 'Sex determination A morphometric parameters of human mandible', International Journal of Research in Medical Sciences, p. 93. doi: 10.5455/2320-6012.ijrms20130511.

Passey, J. et al. (2015) 'Sex determination using mastoid process', Asian Journal of Medical Sciences, pp. 93-95. doi: 10.3126/ajms.v6i6.12406.

Ranganathan, H., Ganapathy, D. M. and Jain, A. R. (2017) 'Cervical and Incisal Marginal Discrepancy in Ceramic Laminate Veneering Materials: A SEM Analysis', Contemporary clinical dentistry, 8(2), pp. 272-278.

Sharma, B. B., Nidugala, H. and Avadhani, R. (2013) 'MASTOID PROCESS - A TOOL FOR SEX DETERMINATION, AN ANATOMICAL STUDY IN SOUTH INDIAN SKULLS', International Journal of Biomedical Research, p. 106. doi: 10.7439/ijbr.v4i2.202.

Sumati et al. (2010) 'Determination of Sex from Mastoid Process By Discriminant Function Analysis', Journal of Anatomical Society of India, pp. 222-228. doi: 10.1016/ s0003-2778(10)80030-9.

Thejeswar, E. P. and Thenmozhi, M. S. (2015) 'Role of mastoid process in determination of sex', Research Journal of Pharmacology and Pharmacodynamics, p. 76. doi: 10.5958/2321-5836.2015.00016.6.

Varghese, S. S., Ramesh, A. and Veeraiyan, D. N. (2019) 'Blended Module-Based Teaching in Biostatistics and Research Methodology: A Retrospective Study with Postgraduate Dental Students', Journal of dental education, 83(4), pp. 445-450.

Verma, R. S. (1996) Genetics of Sex Determination. Elsevier.

Vora, R. K. et al. (2019) 'Determination of Sex from Epicondylar Breadth of Femur', Academia Anatomica International. doi: 10.21276/aanat.2019.5.1.17. 